\title{
THE IMPLEMENTATION OF GUESSING GAME IN TEACHING SPEAKING AT TENTH GRADE OF SENIOR HIGH SCHOOL
}

\author{
Nuraen $^{1}$, Karyati $^{2}$ \\ ${ }^{1}$ IKIP Siliwangi \\ ${ }^{2}$ IKIP Siliwangi \\ ${ }^{1}$ nuraen54@yahoo.com, ${ }^{2}$ karyati634@gmail.com
}

\begin{abstract}
Guessing game becomes an interesting technique which can be implemented by English teachers to teach speaking. Beside rising so much fun, guessing games is believed could increase the students' speaking skill. The aim of this paper is to describe the implementation of guessing game which is utilized by the teacher to improve students' speaking ability at tenth grade of Senior High School. The researchers presented the instruction of how to use guessing games in teaching speaking by teacher in the classroom. Guessing games is a game to guess a thing, person or place, the one of student or group mention the clues and other students as a guesser guess that thing, person or place. Guessing game can help teacher to hire students' participation and students' courage in teaching English. The researchers did the observation to collect the data and find out classroom activity. The result of the research is that the teacher implemented the technique in several steps starting from making group, setting the students to discuss, making them present in front of the class by giving clues, and making the other groups guess what the speaker meant. By doing this activity, the students could develop their skill of speaking in fun way.
\end{abstract}

Keywords : Speaking, Guessing Games.

\section{INTRODUCTION}

Language is a thing that could not be separated from human life. Language has become a tool that human use to communiacate in their life. Human use language to do the interaction with others in delivering the messages. Moreover, language is an immortal thing, it is used continuously in human life as long as they live. Human uses two languages as their tools to communicate. Those are sign language and spoken language, both of them have same intention. In this world, there are many languages that human used. The one of them is English. English is the one of language that have been become the international language. Therefore, english is as a lingua franca because all people in whole the world can use it. They can communicate with foreign people in order to comprehend the message they want to be obtained. According to Florez in (Bailey, 2005) "speaking is an interactive process of constructing meaning that involves producing, receiving and processing information". Therefore, speaking has an important role in human life especially for students who is learning English as the foreign language.

However, it seems that most of students have a big problem in speaking skill. They have some difficulties in speaking English. Based on the writers' perception, it is influenced by students' confident in speaking English, they do not know what vocabularies have to be used when they speak, there is no thing that can encourage them to speak, and their teacher do not teach them 
with an interesting method and the learning do not involve students participation. As a result, students can not practice and enhance their speaking skill. Hence, teacher should be able to cope those problems and improve their teaching method.

Moreover, to make speaking is easier, there should be a good teaching speaking in school. Teaching is a process of transfering knowledge from the sender to the receiver. Teaching has the important role in improving students' speaking skill. Because, it involves students' participation and students' response. Likewise in teaching English, students' participation and students' responses are needed in this process. Therefore, teacher should have an interesting method in teaching English. As the result, it can help teacher to improve students' speaking skill and hire them to speak out in the classroom.

Furthermore, teacher can utilize games in teaching English. Using games in teaching and learning process is very influential to build students' spirit and participation. Games also can hire students' confidence and students' courage to speak. Games is the one of activity that can be utilized by teachers to teach speaking English. The one of fun game is guessing game. According to fitriana (2013) guessing games is a game in which a students recognize something and play it in individually or in a group to carry out it. Hence, the researchers desire to implement guessing games in teaching speaking English and expected can improve students' speaking ability at tenth grade of Senior High School.

\section{LITERATURE REVIEW}

Speaking is a process to communicate among people in delivering utterances. According to Gert and Hans in Efrizal (2012) speaking is speech or utterances with the goal of having intention to be acquainted by sender and the receiver processes the expression in order to recognize their intentions. Speaking is a spoken expression of an interactive process of rising meaning which including phonological and grammatical system and needs the skill to work together in the arrangement of speaking turn in order to convey information and ideas (Argawati, N. O., \& Syahrizal, 2016).

Moreover, Scott, Wendy A. and Ytreberg (1990) believe that speaking is probably the most prosecuting skill for the teacher to teach. Hence, teacher has to teach speaking English and speak English well. In order to have a good skill in speaking English, students have to do more practice, in this case students can practice their speaking skill in classroom with their friends and their teacher.

Moreover, in order to get a good speaking ability, students should have communication skills. Furthermore, according to Harmer (2007) good speaking activities can and should be extremely engaging for the students. If they are all participating fully and if the teacher has set up the activity properly and can then give sympathetic and usefull feedback they will get tremendous satisfaction from it. in speaking activity students are expected to be more active and participate in every situation to establish the successful achievement.

There are several components in teaching speaking, they are pronunciation, fluency, vocabulary use, grammar, comprehensibility, etc.(Brown, 2004).

1. Pronunciation 
Hornby (1985) states that pronunciation is the way how the language is talked, the way in which a word is pronounced, and the way someone talks the words of language. It is the way for students to create clear language when they talk.

2. Grammar

According to Ur (1996) grammar is the way words are lay together to produce a right sentence.

3. Vocabulary

In Hornby (1985), vocabulary can be known as the total number of words that (with ruler for combining them) make up a language

4. Fluency

Brown (2004) states that fluency is about automatizing the language knowledge.

5. Comprehension

Hornby (1985)coined comprehension as the ability to comprehend something.

Furthermore, as an English students, it is important to know what basic types in speaking in order to help students in enrich their speaking ability. According to Brown (2004), there are five basic types of speaking :

1. Imitative

Imitative is the ability to plain parrot back (imitate) a word or phrase or probably a sentence.

2. Intensive

A second type is intensive, it means that the production of short distance of oral language designed to express the ability in a narrow scope of grammatical, phrasal, lexical, or phonological relationships (such as prosodic elements-intonation , stress, rhythm, juncture. The speaker must be aware of semantic properties in order to be able to respond, but interaction with an interlocutor or test administrator is minimal at best.

3. Responsive

Responsive assessment tasks include interaction and test of understanding but at the somewhat limited level of very small conversations, standard greetings and small talk, simple request and comments, and the like.

4. Interactive

The difference between responsive and interactive is in the length and complexity of the interaction, which sometimes includes multiple exchanges and/or multiple participants. Interaction can take the two forms of transactional language, which has the purpose of exchanging specific information, or interpersonal exchanges, which have the purpose of maintaining social relationships.

5. Extensive (monologue)

Extensive include speeches, oral presentations, and story-telling, during which the opportunity for oral interaction from listeners is either highly limited (perhaps to nonverbal responses) or ruled out altogether.

There are so many ways that can be applied by teacher to make fun and interesting teaching and learning process. In English teaching, games is usually used by teacher because it is reputed as a way to improve teaching and learning process. According to (Wright, A., Betteridge, D., and Buckby, 1984) stated in Games for Learning Book, game to mean an activity which is entertaining and engaging, often challenging, and an activity in which the learners play and usually interact with others. Therefore, a good games have to interesting and can hire students' activeness in teaching and learning process. 
Games are ideal for encouraging students to speak and for giving them parctice with functional chunks of language (Shuhan.C.W and Carol, 2008). As a result, a game can make students desire to speak in the classroom. According to Mora, R.A. and Lopera (2001) guessing games is more than just having fun, stress that game and fun activities have always been one of everybodies favorite things to do in class, both for teachers and students since games can contribute to the development of a series of skills and competences. In other word, guessing game increases students' competencies and they can have more than one skill.

Guessing game is activity that includes interaction between individuals of groups aspiring to prescribe aims (Harmer, 2001). Thirumalai (2002) explain that guessing games can be used in teaching speaking. Through guessing games, students can do the teamwork with their friends and change the ideas each other. It can be concluded that guessing game not only effecting in the cognitive side, but also effecting in students' emotional because it can improve students to be socialable.

In each game, there is usually some steps in how to play it. there are some steps in how to play guessing game.According to Sepulveda Janine (2012) there are some steps in how to play guessing game

1. First, one students to come to the front of the class and stand with her or his back to the board.

2. Second, write a word on the board.

3. Third, the rest of the class must give clues to the students until she or he can guess the word (it's alive; you can't find one in this country). Variation : the students at the front of the class must ask yes or no question to the class until she or he guesses the word (is it an animal? Is it in this city?) .

\section{METHOD}

In this paper, the writers used qualitative design. Qualitative research design is a research design that puts principal importance on places primary importance on studying narrow samples of intentionally selected individuals, not attempting to control contextual factors, but rather looking for, by means of a diversity of methods, to apprehend matter from the source points of view, and establish a rich and in-depth picture of the occurence under inspection (Kaswan and Suprijadi, 2016). In this paper, the writers used case study. Case study research method defines as an empirical inquiry that investigates a contemporary phenomenon within its real-life context; when the boundaries between phenomenon and context are not clearly evident; and in which multiple sources of evidence are used (Yin, 1984). To collect the data we did the observation in class X IPA of a senior high school. We observe students and teacher. The writers observed the classroom that was learning English. The wrietrs collected the data using observation sheet to know students' behaviour, classroom activity and the learning process. We want to know whether teacher can satisfy with his or her method and whether or not the method can improve students' speaking ability.

\section{RESULT AND DISCUSSION}

In this paper, the researchers did the observation in the classroom. The researchers 
find some difficulties in students' speaking ability and their motivation in studying English. Therefore, in order to overcome those difficulties, teacher used the interesting activity in teaching English which is guessing game activity. The researchers observed students' motivation, behaviour and classroom activity in English lesson. Figure 1 below describes the implementation of Guessing games by the teacher.

Figure 1. the implementation of Guessing Games

Teacher divided students into seven groups, each group consist of five students

Teacher asked each group to do discussion base on the pictures they got; they have to find some characteristics and physical appearance of the pictures member of the group have their own task

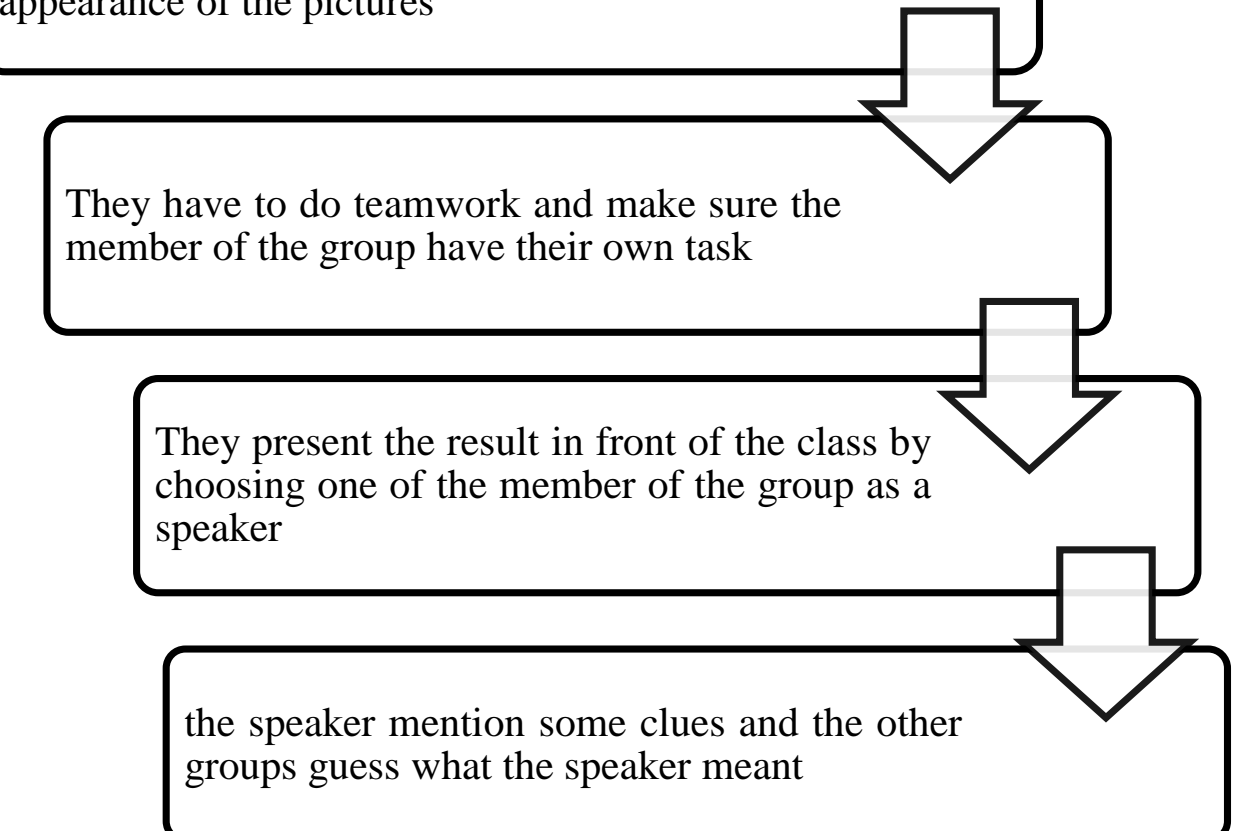

The researchers observed students' behaviour during discussion. Based on the oservation, the researchers found that the most of groups did a good discussion and they did a good teamwork. Most of them find some difficult vocabularies but they can overcome their problem with some help from their members. The researchers also observe their motivation in studying English. Actually they have a great spirit and high motivation in studying English. They have a higher motivation when they study English using an interesting activity. In this case, teacher taught students using guessing game activity that build students' motivation. They also can explore and deliver their idea and opinion during the discussion process.

When they talk in front of the class, each group had choosen their members as the speaker it consist of three sttudents. Those students speak out to other groups and present the result of the discussion that is mention some clues that had been made. The researchers found that students 
produce little bit of wrong pronunciation but it is not too bad. Teacher gave the correction on it. They also very confidence in speaking in front of the class, because they had a well preparation. Table 1 below is the observation sheet used by the researchers.

Table 1. Observation Sheet

\begin{tabular}{l} 
Group : IPA $4 \quad$ Teacher : Yoan Farida S.Pd Number of Students : 35 \\
\hline Classroom : X \\
General attitude of students towards learning (motivation, interest, participation, \\
etc). \\
Students motivation, interest and participation was really great during the lesson. \\
They were very exciting and gave high antusiasm in the learning process. Firstly, \\
they had some difficulties in describing people, but after they study English use \\
guessing game they were easier to describe people because they thought it is as a \\
fun activity. They had high motivation to learn because teacher gave a reward to \\
the group that got a highest score.
\end{tabular}

Use of mother tongue

1. Students : they often use their mother tongue, but when they play guessing game, they used English and forget their mother tongue.

2. Teacher : she/he mix the language during teaching and learning process, sometime English sometime bahasa Indonesia, because when teacher use English full students can not follow the lesson.

Use of English in Classroom

1. Students : they used English when play guessing games

2. Teacher : teacher used English not fully

Distribution of the lesson

1. Sequence of activities :

- Students divided into seven groups each group consist of five students.

- Teacher gives three the famous person pictures to each group and teacher asks students to discuss the pictures and find some their physical appearance and characteristics to help them in describing to other groups.

- Teacher gives ten minutes to each group to do the discussion.

- Teacher asks each group to come forward and mention some clues about the pictures, the group tell the first clue and if there is no guesser that can not guess it the group can continue to next clue until the guessers can guess it. The group that can guess the pictures they get 100 points from teacher.

2. Time spent : $2 \times 45$ minutes

Support media used

- Celebrities Pictures 
The first, the writers observed students' behaviour during discussion. Based on the oservation, the writers found that the most of groups did a good discussion and they did a good teamwork. Most of them find some difficult vocabularies but they can overcome their problem with some help from their members. The writers also observe their motivation in studying English. Actually they have a great spirit and high motivation in studying English. They have a higher motivation when they study English using an interesting activity. In this case, teacher taught students using guessing game activity. They also can explore and deliver their idea and opinion during the discussion process. But there are still some of students have low motivation in learning speaking. it could be seen when they do discussion with their groups. There are some students who do not aware and give their participation in discussion process. They only listen to their friends discussion without giving their idea or opinion.

The second, the writers found that students had some difficulties and even did not want to describe the pictures that they got. Those difficulties were a lack of vocabulary and they afraid they will be wrong in pronounce the words. Moreover, after teacher used different method which is guessing game activity, Students' motivation was increased and they were more confidence to speak out in front of the class. And even most of them that did not want to speak out previously but after they learn speaking using guessing game activity they got a courage to speak.

And beside that guessing game also enrich students' vocabulary and improve students' pronunciation. They got many vocabularies after studying descriftive using guessing game activity. Teacher also correct students' pronunciation. As a result, they are very confidence in speaking in front of the class, beside they can pronounce the words rightly they also have a well preparation. Beside that, teacher also get students' participation because the teacher use an interesting method that can grab students' excitement. As a result, teaching and learning process is better than the previous one. Students was not afraid to speak in front of the class because the learning process is more fun.

Based on the data above, it could be concluded that the teacher already successed in teaching speaking using guessing game activity. Teacher made teaching and learning process more active and fun than usual. Teacher has a well preparation before teaching so the teaching and learning process run smoothly. Teacher also presented materials is easy to be understood by students and the material is appropriate with students life so it makes easier for students to understand the material. Teacher also gave the clear direction so students can follow the game. Teacher also aware to what students need and encourage them to do their best in play guessing game. Beside that, teacher asked students to more active that is to free asking questions, and deliver their opinion. As a result, as an English teacher, guessing game can be used by English teacher in every classroom situation. Because it can become a classroom situation more fun and active. Teacher will not feel bore as long as teaching and learning process run.

\section{CONCLUSION AND SUGGESTION}

After doing the oservation, the researchers conclude that:

1. Most of students already had a good speaking skill because they looked very confidence and exciting when teacher asked them to do the speaking class.

2. They also has a higher motivation after they study English using guessing game activity, they can cooperate with their groups and increase their confidence to deliver their opinion. 
3. In implementing a guessing game, students can improve their speaking ability. They more speak English than bahasa Indonesia. They cooperate with their group before they play the game so they have a good preparation on what they are going to talk. It can increase and help them to speak in front of the class.

The reserachers suggest that using guessing game in teaching English speaking is very influence to improve students' speaking ability. Guessing game activity is very fun activity because students can cooperate with their friends, they can deliver their opinion, and they do not realize that they are learning while palying so teacher gets students' participation. Teacher can use guessing game in teaching English speaking and we hope guessing game activity can help teacher to improve students' speaking ability.

\section{REFERENCES}

Argawati, N. O., \& Syahrizal, T. (2016). The Use Of Task-Based Instruction To Improve Speaking Skill To The Second Semester Students Of Stkip Siliwangi Bandung On The Academic Year Of 2014-2015. Jurnal Ilmiah UPT P2M STKIP Siliwangi, Vol.3, 1-8.

Bailey, K. . (2005). Practical English Language Teaching: Speaking. New York: The Mc Graw Hill Companies, Inc.

Brown. (2004). Language Assessment: Principles and Classroom Practices. London: Pearson Education. Inc.

Efrizal. (2012). Improving Students' Speaking through Communicative Language Teaching Method at Mts Ja-alhaq Sentot Ali Basa Islamic Boarding School of Bengkulu, Indonesia. Bengkulu.

Fitriana. (2013). Improving the Speaking Skills through Guessing Games.

Harmer. (2001). The Practice of English Language Teaching. Hong Kong: Longman.

Hornby. (1985). Oxford Advanced Learner's Dictionary. Oxford University Press.

Jeremy Harmer. (2007). How to Teach English.

Kaswan and Suprijadi. (2016). Research in English Language Education. Bandung: Putra Praktisi.

Mora, R.A. and Lopera, M. . (2001). Games in classroom more than just having fun. A Colombian Journal for Teachers of English.

Scott, Wendy A. and Ytreberg, L. H. (1990). Teaching English to Children. London: Longman. Sepulveda Janine. (2012). 50 ways to Teach Speaking Tips for ESL/EFL. The United States: Wayzgoose press.

Shuhan.C.W and Carol. (2008). Flying with Chinese. Marshal Cavendish Education.

Thirumalai, M. (2002). An Introduction to TESOL: Teaching English to Speaker Other Language.

Ur. (1996). A Course in Language Teaching. Cambridge: Cambridge University Press.

Wright, A., Betteridge, D., and Buckby, M. (1984). Games for Language Learning. Cambridge: Cambridge University Press.

Yin, R. K. (1984). Case Study Research: Design and Methods. Beverly Hills, Calif: Sage Publications. 